\title{
Doktor Maria Kujawska (1893-1948) - życie i działalność
}

\section{Dr. Maria Kujawska (1893-1948) - her life story and activities}

\author{
Krystyna Czernik ${ }^{1}$
}

Opole

Streszczenie: Artykuł przedstawia życie i działalność zawodowa Marii Kujawskiej (1893-1948), jedynej kobiety uczestniczącej jako lekarz w III Powstaniu Śląskim. Studia lekarskie rozpoczęła we Wrocławiu, kontynuowała w Monachium i Krakowie, a ukończyła w Warszawie. Po zakończeniu III Powstania Śląskiego pracowała w szpitalu, wykładała na kursach pielęgniarskich w Myślenicach i uczestniczyła w działalności jednego z narodowych ugrupowań politycznych oraz w Towarzystwie Polek. Po wybuchu II wojny światowej udało się jej zbiec do Rumunii, a potem do Jugosławii. W Crkvenicy szwajcarska organizacja Pro Polonia zorganizowała ochronkę, w której pracowała pod przybranym nazwiskiem Kujawska. W 1943 roku placówka została przeniesiona na wyspę Krk. Na początku 1944 roku Niemcy zajęli Jugosławię i aresztowali pracowników tej placówki. Kujawska została wywieziona wraz z córkami do niemieckiego obozu koncentracyjnego w Ravensbrück. W 1945 roku, tuż przed wyzwoleniem obozu zdołała z niego uciec. Po zakończeniu II wojny światowej pracowała jako lekarz w Pszczynie i tam zmarła.

Abstract: This article presents life and activities of Dr. Maria Kujawska (1893-1948), the only woman participating as a physician in the Third Silesian Uprising. She studied medicine in Wroclaw, Munich, Cracow and Warsaw where she obtained her doctor degree. After the Third Silesian Uprising she worked in a hospital, gave lectured at the Red Cross Nursing School in the town of Myslenice. Moreover, she was an active member of some national political party and the Female Polish Society. After the outbreak of the Second World War she had to escape to Romania and next to Yugoslavia. In Crkvenica some Swiss society organized a kind of orphanage for Polish children where Kujawska worked under a false name. In 1943 this orphanage was transferred to the island of Krk. In 1944 the Germans occupied Yugoslavia and arrested the staff. Kujawska was sent to the German concentration camp in Ravensbrück. In 1945, Kujawska escaped just before the liberation of the camp. After the end of the war she worked as a physician in the town of Pszczyna where she died.

Słowa kluczowe: III Powstanie Śląskie, Maria Kujawska, lekarze w powstaniach śląskich, niemiecki obóz koncentracyjny w Ravensbrück

Keywords: Third Silesian Uprising, Maria Kujawska, doctors in Silesian Uprisings, German concentration camp in Ravensbrück 
...Wartość lekarzy mierzymy zwykle ich zastugami dla nauki, o uczonych lekarzach rozpisujemy się obszernie, milczymy zaś uparcie o cichych, a zastużonych pracownikach społecznych. Czyny bohaterskie takiego pracownika więcej zastuguja na uznanie, aniżeli niejedno pośpieszne, a niedojrzałe odkrycie naukowe...

doktor Władysław Biegański

Maria Kujawska z domu Raida (spolszczone Rajda) ) urodziła się 5 lipca 1893 roku w Raciborzu. Ojciec Wilhelm Rajda był mistrzem szewskim, matka gospodyni domowa ze Świdnicy z domu Jendrischek „...pochodziła ze zgermanizowanej rodziny ślaskiej..". Szkołę powszechną ukończyła w Raciborzu. Ponieważ do gimnazjum realnego i humanistycznego przyjmowano wyłącznie chłopców, Maria ukończyła szkołę średnia „Fraulein Pruss”, która jednak upoważniała do wyższych studiów. W 1912 roku uzyskała świadectwo dojrzałości. Ojciec chciał, aby Maria przede wszystkim uzyskała przygotowanie pedagogiczne, a później wybrała studia wyższe. W 1915 roku wraz z młodszym bratem Hansem Maria rozpoczęła studia na wydziale medycznym

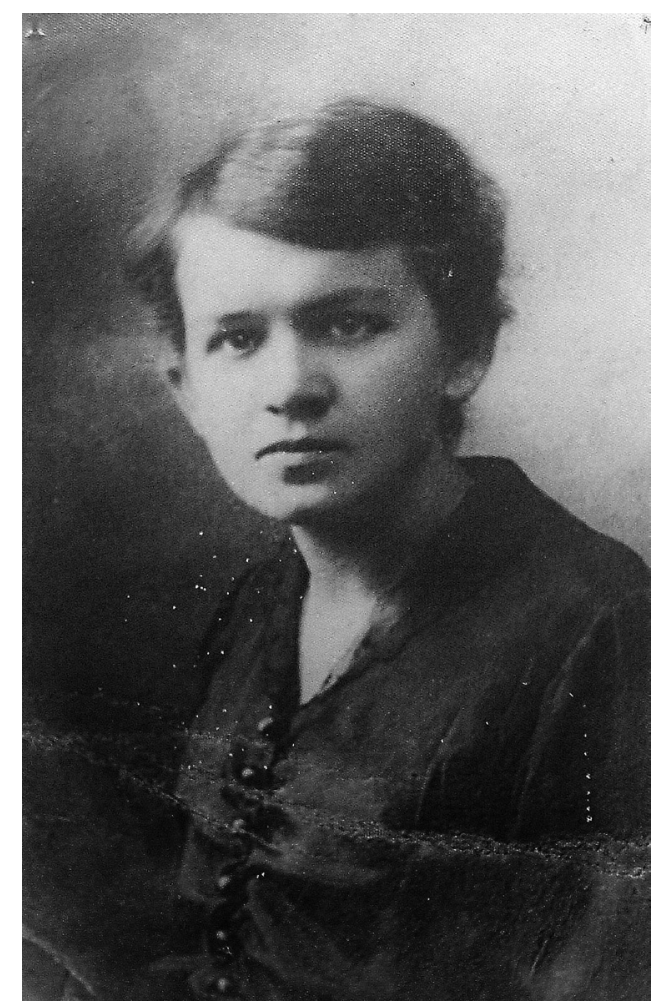

Ryc. 1. Maria Rajda 
Uniwersytetu we Wrocławiu². Tam nawiązała liczne przyjaźnie ze studentami z Polski „.. i niezwłocznie zaczęła uczyć się po polsku...”3. Wstapiła do tajnej, niepodległościowej organizacji studenckiej Związku Młodzieży Polskiej „Zet”, zwanego Związkiem Młodej Polski, który powstał w 1918 roku. Z tego okresu datuje się znajomość i współpraca z innymi działaczami śląskimi, takimi jak: Alfons Zgrzebniok, Jan Wyglenda, Karol Grzesik, Adam Kocur, a także Michałem Grażyńskim ${ }^{4}$. Działalność w Związku Młodzieży Polskiej „Zet” ukształtowała poglądy ideologiczne dr Marii, która w późniejszym okresie życia należała do zwolenników Józefa Piłsudskiego.

Dalsze studia medyczne Maria kontynuowała kolejno w Monachium i Krakowie, a dyplom lekarski i doktorat uzyskała w Warszawie 15 sierpnia 1920 roku. Po ukończeniu studiów wróciła na Śląsk. Był to czas obfitujący w ważne wydarzenia. Działacze niepodległościowi po II Powstaniu Ślasskim przygotowywali się do plebiscytu. Spodziewano się, że w wyniku mającego odbyć się plebiscytu cały Górny Śląsk przypadnie Polsce. W związku z tym Wydział Zdrowia Publicznego wspólnie z Polskim Czerwonym Krzyżem chciał przygotować średni personel medyczny do pracy w przyszłym województwie śląskim. Dlatego też pod koniec 1920 roku zorganizowano kurs pielęgniarski. Przygotowanie kadry polskich położnych powierzono dr Marii Rajda-Kujawskiej, która założyła polskie związki położnych w prawie wszystkich powiatach Górnego Śląska 5 .

Posługiwano się terminem „położna” w odróżnieniu od nie mającego rodzimego pochodzenia słowa akuszerka. Również w ramach akcji plebiscytowej, PCK pod koniec 1920 roku zorganizował dla regionu śląskiego oficjalny kurs sanitarny. Ten kurs miał na celu przede wszystkim wykształcenie polskich sióstr Czerwonego Krzyża oraz wykształcenie polskiego średniego personelu medycznego dla polskiej służby zdrowia na Śląsku. Szkoleniem pielęgniarek zajmowali się lekarze, wśród nich znajdowała się dr Maria Rajda. Polacy bardzo starannie przygotowywali się do plebiscytu. Kształcono kadry medyczne na przyszłość, nie zapominając o zabezpieczeniu opieki medycznej dla ludności polskiej mieszkającej na Śląsku, jak i również przybyłej tam na okres plebiscytu. Obawiano się akcji zbrojnych i prowokacji ze strony Niemców.

W dniu plebiscytu 20 marca 1921 roku dr Maria Rajda pełniła dyżur lekarski w hotelu „Lomnitz” w Bytomiu, gdzie znajdował się polski sztab plebiscytowy. Niestety wbrew oczekiwaniom wyniki plebiscytu okazały się dla Polski niekorzystne. W maju 1921 roku wybuchło III Powstanie Śląskie.

Doktor Maria razem z innymi lekarzami utworzyła punkty opatrunkowe dla rannych powstańców. Sama pracowała w jednym z takich punktów kolejno w Szopienicach, ,...w Rożdzieniu, Małej Dąbrówce później prowadziła pociąg sanitarny z frontu Grupy „Wschód” do Sosnowca, w drugiej połowie maja została lekarką szpitala polowego w Toszku a następnie w stopniu porucznika lekarza w Głównym Szpitalu

\footnotetext{
H. Biegańska, Działaczka ślaska Maria Kujawska, „Dzieje Najnowsze”. 1970, nr 1, s. 180.

Instytut Śląski w Opolu, sygn. A 2029, Kujawska Maria , Materiały do bibliografii.

E. Długajczyk, Sanacja śląska 1926-1939. Zarys dziejów politycznych, Katowice 1983, s. 175-176.

5 K. Brożek, Polska stużba medyczna w powstaniach ślaskich i plebiscycie 1918-1922, Opole 1977, s. 73.
} 


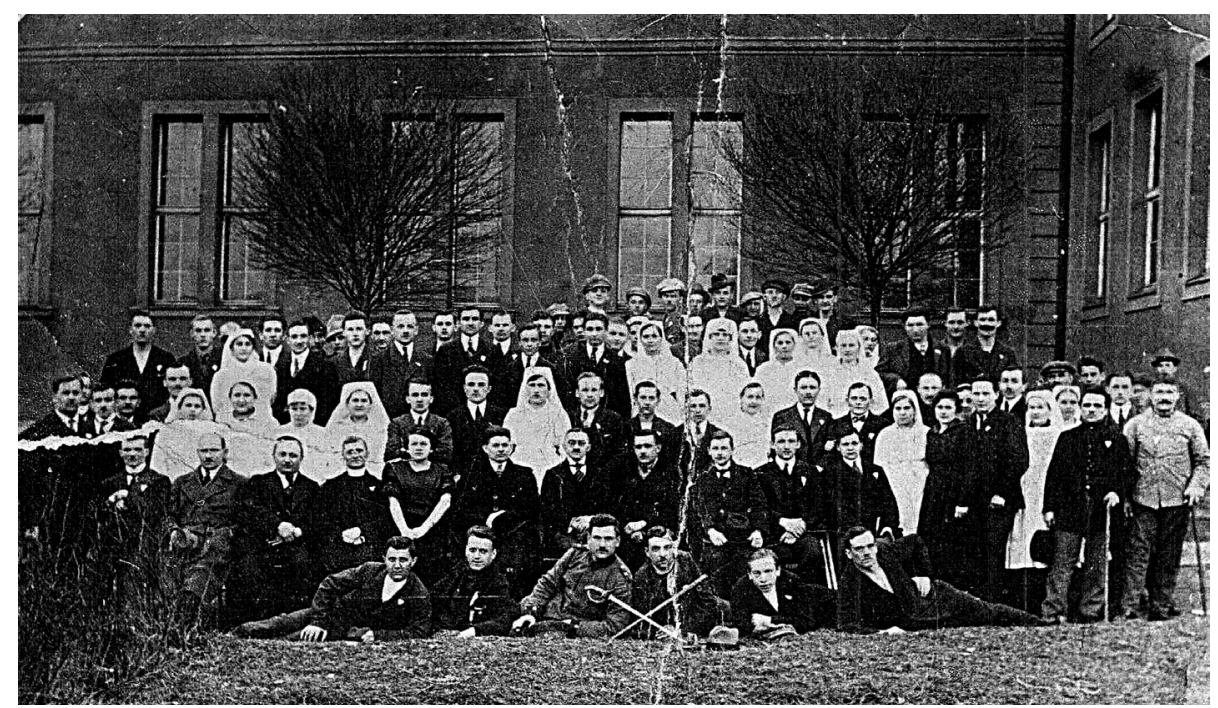

Ryc. 2. Personel Górnośląskiego Szpitala PCK

Wojsk Powstańczych w Mysłowicach...”' . „..Była jedyną kobietą lekarzem w trzecim powstaniu, jeżeli nie liczyć, kilku studentek medycyny...."7.

W dniu 16 sierpnia 1921 roku, już po zakończeniu powstania, doktor Maria Rajda wyszła za mąż za swojego kolegę, powstańca i lekarza Kazimierza Kujawskiego. Do stycznia 1922 roku dr Maria Kujawska pracowała w szpitalu mysłowickim, który nazywano Górnośląskim Szpitalem PCK. W okresie od 20 lutego do 20 maja 1922 roku była wykładowcą na kursie dokształcającym siostry PCK, które chciały w przyszłości zostać pielęgniarkami, zorganizowanym w szpitalu w Myślenicach. „...Program (kursu) po za pielęgniarskimi zajęciami teoretycznymi i praktycznymi obejmował również wykształcenie ogólne w zakresie języka polskiego, literatury, historii i geografii ..."8. W lipcu 1922 roku dr Maria Kujawska otrzymała za swój ogromny wkład pracy w III Powstaniu Śląskim odznaczenie Polskiego Czerwonego Krzyża II stopnia9.

Racibórz po powstaniu pozostał w rękach niemieckich, dlatego też Maria nie mogła wrócić do swojego rodzinnego miasta. W latach 1922-1923 prowadziła oddział PCK w Katowicach. Później związała się ze środowiskiem działaczy społecznych z Brzezin Ślasskich, gdzie osiedliła się w 1923 roku i zamieszkała z mężem przy ulicy Warszawskiej $15^{10}$. W tym czasie (do 1932 roku) pracowała w Poradni PCK. Doktor Kujawska nie zaniedbując pracy zawodowej znajdowała czas na pracę społeczna. Ak-

\footnotetext{
K. Brożek, Polska stużba..., s. 189.

K. Brożek, Anioł z Ravensbrück, „Opole” 1974, nr 4 s. 14.

K. Brożek, Polska stużba..., s. 189.

Tamże, s. 185.

10 J. Rostek, Spis lekarzy województwa ślaskiego. Według stanu z dnia 1 lutego 1924 r., „Goniec Śląski Towarzystwo Akcyjne" 1924, s. 4.
} 


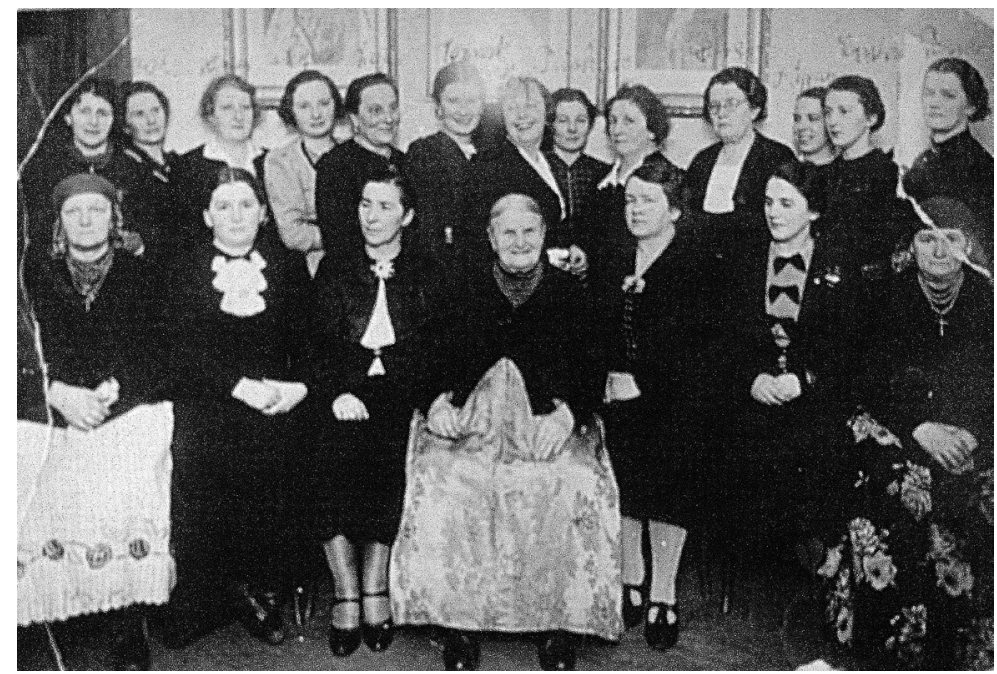

Ryc. 3. Towarzystwo Polek

tywnie działała jako jedyna lekarka w gronie założycielek i długoletnia wiceprzewodnicząca w Towarzystwie Polek. Aktywny udział w życiu społecznym i politycznym Śląska zaowocował wystawieniem jej kandydatury jako posła na Sejm Śląski. W dniu 11 maja 1930 roku doktor Maria Kujawska w wyborach do drugiego Sejmu Śląskiego uzyskała mandat posła z ramienia Narodowego Chrześcijańskiego Zjednoczenia Pra$\mathrm{cy}^{11}$. Rzecznikiem sanacji na Śląsku był wtedy doktor Michał Grażyński.

Doktor Maria i Kazimierz Kujawscy „....stali na stanowisku, że w ówczesnej sytuacji (Śląska) potrzeba było silnego rządu, dlatego zgodnie ze swoimi przekonaniami w pełni popierali program sanacji..."12.

Po przeciwnej stronie barykady politycznej stało ugrupowanie pod wodza Wojciecha Korfantego. Oba te ugrupowania zaciekle się zwalczały. Jak goracy to był czas, jak czasami bezpardonowe metody stosowali adwersarze niech świadczy fakt, że w czerwcu 1930 roku „..doktor Kujawski dopuścił się rękoczynu na Korfantym w obronie swojej żony, posłanki, obrażonej przez Kofrantego (...) na jednym z posiedzeń sejmu śląskiego...”13. Między innymi w wyniku tego incydentu i „przy akompaniamencie brukowej kampanii i nagonki przeciwko Korfantemu 30 czerwca 1930 roku przedwcześnie zamknięta została sesja Sejmu Śląskiego..." ${ }^{14}$. Obrady Sejmu wznowiono 9 września 1930 roku, ale już 29 września został on rozwiazzany ${ }^{15}$. Rozpisano wybory i ponownie, 29 listopada 1930 roku, Kujawska zdobyła mandat poselski

11 E. Długajczyk, Sanacja ślaska..., s. 167.

12 W. Biegańska, Działaczka śląka..., s. 180.

13 M. Orzechowski, Wojciech Korfanty. Biografia polityczna, Wrocław 1974, s. 339.

14 Tamże.

15 E. Długajczyk, Sanacja ślaska..., s. 255. 


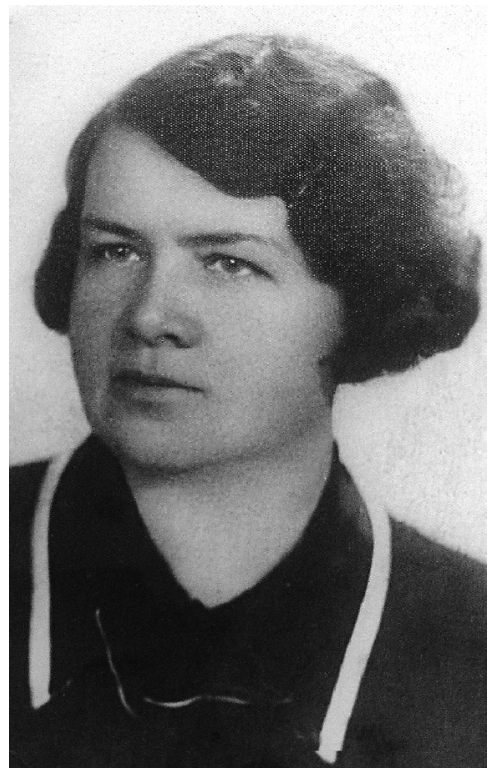

Ryc. 4. Dr Maria Kujawska

z ramienia Narodowo-Chrześcijańskiego Zjednoczenia Pracy, tym razem na III kadencję Sejmu Ślaskiego.

Oprócz pracy poselskiej Maria Kujawska aktywnie działała w Narodowo-Chrześcijańskim Zjednoczeniu Pracy. Jednak w latach 1931-1933 nastapiło znaczne zahamowanie działalności tej partii. Ożywienie nastapiło w połowie 1934 roku. W dniu 17 października 1934 roku wybrano nowe władze i uchwalono nowy statut. Maria Kujawska została ławnikiem w Głównym Komitecie Wykonawczym ${ }^{16}$.

Dlatego też dużą niespodzianką stało się wyeliminowanie jej w czasie rozgrywki o mandaty $w$ wyborach do Sejmu we wrześniu 1935 roku. Ta niewatpliwie przykra niespodzianka nie zniechęciła Marii, która nie wycofała się z życia politycznego. Ani na chwilę nie przestała być również lekarzem. Oboje z mężem byli pełni poświęcenia dla każdego potrzebującego, dla każdego chorego. Żyli bardzo skromnie, przeznaczając stale część swoich dochodów na cele społeczne „,...choćby w formie obiadów dla pięciu rodzin bezrobotnych..."17.

W grudniu 1936 roku Maria Kujawska weszła w skład Rady Wojewódzkiej jako jeden z pięciu członków wybranych w głosowaniu i do wybuchu wojny była aktywna w tym naczelnym organie administracji Śląska, którego program obejmował spolszczenie przemysłu, administracji i szkolnictwa, a także walkę z nędzą mieszkaniowa i bezrobociem ${ }^{18}$.

W owym czasie Ślassk był areną wielu rozgrywek politycznych. Ścierały się różne poglądy i ideologie, większość działaczy i polityków miało ten sam cel - zjednoczenie Śląska z Polską. Różne był jednak wizje tych działań. Niezależnie od walki dwóch głównych ugrupowań politycznych, na czele których stali Wojciech Korfanty i Michał Grażyński, walki toczyły się w łonach samych partii. W wyniku wewnętrznych rozgrywek NChZP powołało do życia Obóz Zjednoczenia Narodowego (OZN) w dniu 28 czerwca 1937 roku, doktor Maria Kujawska weszła w skład Prezydium Okręgu Śląskiego OZN ${ }^{19}$.

W 1938 roku Kujawska, popierana przez Kobiecy Komitet Wyborczy, startowała w wyborach do Sejmu Ślaskiego, „otrzymała 25.000 głosów, co się jednak okazało niewystarczającym dla uzyskania mandatu..." ${ }^{20}$.

Doktor Kujawska niezależnie od działalności politycznej brała czynny udział w życiu środowiska lekarskich na Śląsku. Była członkiem Towarzystwa Lekarzy Polaków

16 Tamże, s.286.

17 H. Biegańska, Działaczka śląska..., s. 181.

18 Tamże.

19 E. Długajczyk, Sanacja śląska..., s. 324-325.

20 W. Bałutis, Kobiety wczoraj, dziś i jutro, „Głos Polek” 1939, nr 5-6, s. 11. 


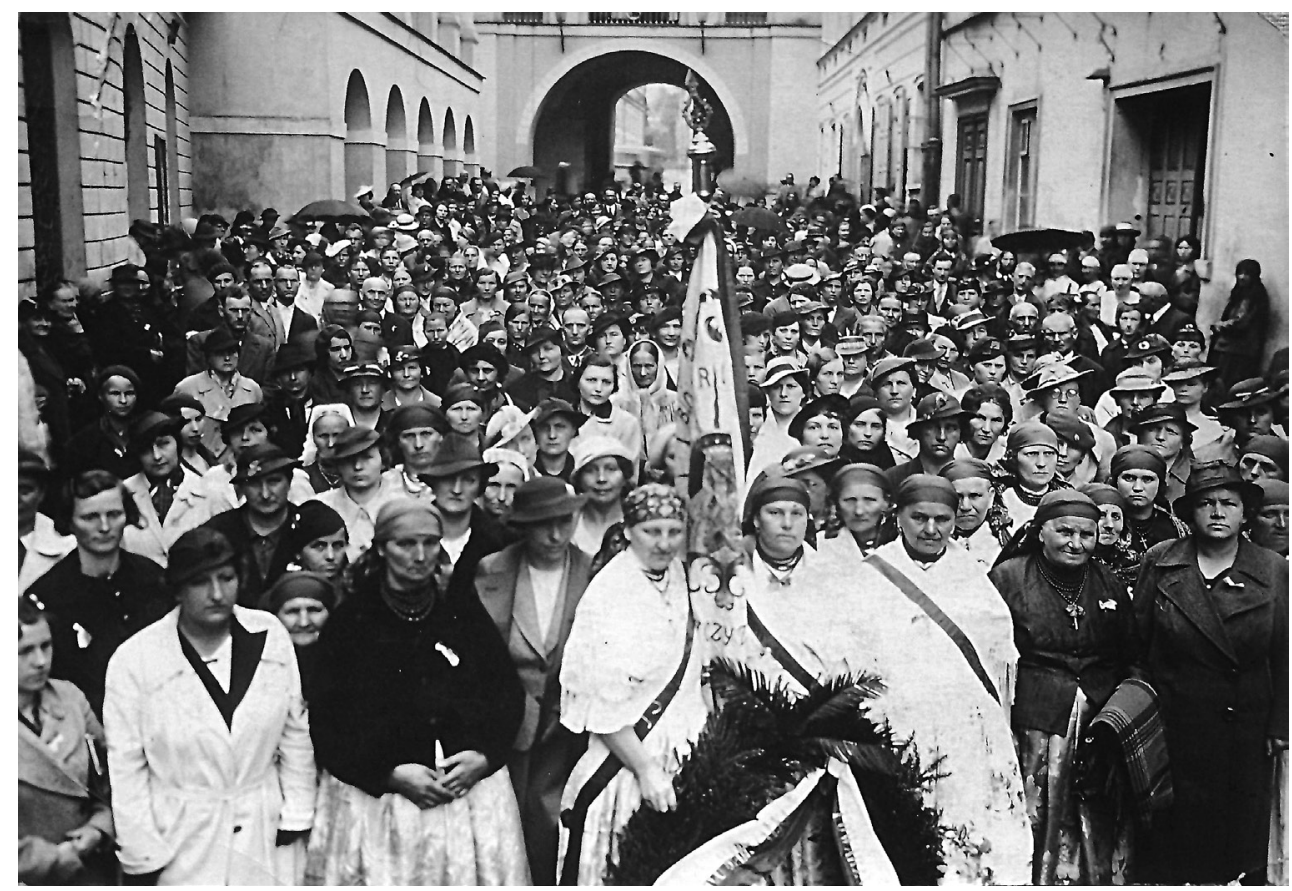

Ryc. 5. Dr Maria Kujawska wśród Ślązaków w Wilnie

na Śląsku, Związku Gospodarczego Lekarzy Polaków Województwa Śląskiego, Śląskiej Izby Lekarskiej ${ }^{21}$.

Zadziwiające jest, skąd czerpała siły ta drobna kobieta, żona i matka czterech córek na tyle obowiązków, pracę zawodowa, społeczną i działalność polityczna. Doktor Maria była również autorka szeregu publikacji prasowych o charakterze społeczno-politycznym, które zamieszczane były na łamach katolickiej „Polski Zachodniej” i „Głosu Polek" ${ }^{\prime 22}$.

Pracowite życie i działalność polityczna przerwał wybuch wojny w dniu 1 września 1939 roku. Doktor Maria Kujawska jako znana działaczka śląska musiała uciekać z Polski. W drugiej połowie września Niemcy przeprowadzili rewizję w jej opuszczonym domu i rozesłali listy gończe. Ten okres w życiu doktor Marii znamy dzięki wspomnieniom współpracowniczki, doktor Agnieszki Appelt. W przeddzień wybuchu wojny doktor Kujawska wywiozła swoje trzy córki do rodziny pod Koluszki. Najstarsza córka, Aleksandra w tym czasie przebywała w Anglii, gdzie studiowała medycynę. Mąż, Kazimierz Kujawski, też wyjechał. Nie spotkali się już aż do zakończenia wojny. Doktor Kazimierz, ukrywając się, prowadził praktykę lekarską między innymi w Kłobucku, Skarżysko-Kamiennej i Częstochowie ${ }^{23}$.

21 K. Brożek, Anioł..., s. 24.

22 Tamże.

23 Słownik medycyny i farmacji Górnego Ślaska, pod red. A. Puzio, t. 1, Katowice 1993, s. 161. 
Maria Kujawska najpierw organizowała obozy dla ewakuowanych, później wyjechała do Rumunii. Następnie z transportem matek i dzieci udała się do (ówczesnej) Jugosławii. Tam też spotkała się ze swoimi córkami. W Crkvenicy szwajcarska organizacja Pro Polonia zorganizowała Home Suisse pour Enfants Polonais ${ }^{24}$. W tym czasie dom prowadzony przez Marię Kujawską odwiedził Stanisław Ligon, który obszerne sprawozdanie ze swej wizyty zamieścił w Wieściach Polskich w 1940 roku, które wydawane były w Budapeszcie. W sierpniu 1943 roku Włosi przenieśli siedzibę tej placówki do miejscowości Malińsk na wyspie $\mathrm{Krk}^{25}$.

Na początku 1944 roku Jugosławię zajęli Niemcy. Gestapo aresztowało wszystkich pracowników domu. Kobiety i dzieci powyżej 14 roku życia trafiły do Ravensbrück. Maria najmłodszą córkę zdołała wysłać do rodziny do Raciborza. Sama z dwoma córkami, Janiną i Barbara, 24 stycznia 1944 roku trafiła do obozu razem z 55 innymi kobietami. Otrzymała numer obozowy $26504^{26}$.

Po odbyciu kwarantanny razem z córkami trafiła na blok trzeci. Nieustannie wisiała nad nia groźba identyfikacji, jako osoby poszukiwanej przez gestapo. Została wciagnięta przez inne Polki do pracy w rewirze. W obozie doskonała znajomość języka niemieckiego była dla Marii wręcz nieoceniona. Pracę rozpoczęła na bloku dziesiątym rewirowym, który przeznaczony był dla kobiet chorych na gruźlicę i psychicznie chorych. Działalność medyczna była praktycznie niemożliwa. Cały jej wysiłek skupiał się na działaniach majacych na celu poprawienie warunków przebywania w rewirze, zdobywaniu dodatkowych racji żywieniowych dla swoich podopiecznych. Często udawało się jej wyjednać najbardziej potrzebne lekarstwa. Jej postawa budziła szacunek nawet wśród niemieckich obozowych lekarzy. Niestety zaciekły wróg doktor Kujawskiej, szwajcarska więźniarka Carmen Mory współpracująca z Niemcami, spowodowała przeniesienie Marii ${ }^{27}$. Nowym zadaniem, jakie jej powierzono, była opieka nad 80 psychicznie chorymi kobietami, które przebywały w niewielkim pomieszczeniu. Z nimi za karę została zamknięta doktor Kujawska, aby je „leczyć”. Gehenna ta na szczęście trwała krótko, bo sama w listopadzie 1944 roku rozchorowała się na dur wysypkowy. Jej choroba trwała długo, przeżyła „dzięki ofiarnej i serdecznej opiece doktor Zofii Adamskiej i pielęgniarki Wandy Wójcik"28. Okres rekonwalescencji doktor Maria spędziła przy badaniach wstępnych nowoprzybyłych do obozu kobiet. Tam stykała się z kobietami przywiezionymi z powstańczej Warszawy. Starała się zapoznać je z warunkami w obozie, do kart nie wpisywała żadnych poważnych dolegliwości, byłby to bez watpienia wyrok śmierci dla tych kobiet. Ostatni okres pobytu w obozie doktor Kujawska spędziła w bloku jedenastym rewirowym. Panowały tam dużo lepsze warunki, ale lekarze niemieccy przeprowadzali częste selekcje więźniarek.

24 H. Biegańska, Działaczka śląska..., s. 181.

25 Tamże.

26 W. Kędrzyńska, Sylwetki zastużonych lekarzy. Dr Maria Kujawska, „Przegląd Lekarski” 1965, nr 1, s. 166.

27 Tamże, s. 167.

28 Tamże, s. 167.

29 W. Kędrzyńska, Sylwetki zasłużonych..., s. 167. 
Podczas generalnej selekcji doktor Kujawska zdobyła się na czyn bohaterski. Zorientowała się, że komisja dokonuje selekcji w sąsiednim rewirze, wygłosiła do chorych przemowę, ryzykując denuncjacja, ponieważ wśród chorych przebywał różny element. Nakazała chorym wstać z łóżek, ubrać się jak najstaranniej, uczesać. Nikt nie mógł wyglądać na chorego. „Gdy przyszła komisja, zastała w otwartych oknach kobiety roześmiane, o dobrym wyglądzie. Dr Kujawska z pogodna twarzą wyszła naprzeciw niemieckich lekarzy i mocnym spokojnym głosem oświadczyła, że w tym bloku poważnie chorych nie ma" ${ }^{\prime 29}$, właśnie to uratowało blok jedenasty przed selekcja na śmierć. Był to wspaniały postępek, który wywarł na więźniarkach ogromne wrażenie. Dwa lata po wojnie, w 1947 roku, szwajcarska więźniarka Gertruda Kyzer Lanz, udzielając wywiadu dziennikarzowi „Ekspresu Wieczornego”, szczegółowo opisała to całe zdarzenie ${ }^{30}$. To samo zdarzenie znalazło swoje odbicie w licznych wspomnieniach więźniarek z Ravensbrück. Jej poświęcenie, oddanie, odwaga, hart ducha zaskarbiły doktor Marii ogromny szacunek i sympatię, dlatego nadano jej przydomek „Anioł z Ravensbrück”.

Tuż przed wyzwoleniem obozu doktor Marii Kujawskiej udało się z niego zbiec wraz z córkami. Ukrywając się, doczekały się wyzwolenia. Od władz szwajcarskiego Czerwonego Krzyża otrzymała propozycję pozostania w tym kraju. Serce nakazywało jednak powrót do "domu”, na Śląsk. Wróciła, zamieszkała w Pszczynie i tam dopiero dane jej było spotkać się z mężem po długiej, wojennej rozłące. Rozpoczęła pracę jako kierownik Powiatowego Ośrodka Zdrowia w Pszczynie ${ }^{31}$. Wkrótce, bo 28 listopada 1945 roku, zmarł jej mąż, doktor Kazimierz Kujawski. Cały ciężar utrzymania rodziny spadł na barki tej dzielnej i jakże doświadczonej przez los kobiety. W tym okresie pracowała w przychodni przeciwgruźliczej, poradni dla dzieci i dla kobiet ciężarnych ${ }^{32}$. Nawet nie myślała o założeniu prywatnej praktyki. Cały swój wysiłek i pracę poświęciła dla chorych i biednych. Dla nich to trzy razy w tygodniu jeździła do Katowic, by wywalczyć tam przydziały leków, żywności i odzieży. Ciężkie przeżycia wojenne, wyczerpująca praca zawodowa, utrata ukochanego męża, miały wpływ na zdrowie doktor Kujawskiej. Ostatnie miesiące jej życia tak wspomina doktor Agnieszka Appelt.

„....Oleńka studiowała medycynę w Anglii, była na V roku. Dr Kujawska uparła się, że ona musi wrócić do kraju. Odradzaliśmy jej, niech przynajmniej tam skończy studia, ale nie, nie dała się przekonać. Wysłała list i Oleńka wróciła, za dwa miesiące, jakby przeczuwała, umarła mając wszystkie córki przy sobie...." ${ }^{33}$. Doktor Maria Kujawska zmarła nagle na serce w dniu 23 maja 1948 roku. Pochowana została w Pszczynie.

Odznaczona została Krzyżem Kawalerskim Polonia Restituta. Jej dzieło niesienia pomocy chorym kontynuowały córki: Aleksandra, Janina, Barbara i Maria. Wszystkie zostały lekarkami.

30 L. Chrzanowski, Jak dr Maria Kujawska uratowała swe blokowe towarzyszki od straszliwej śmierci w komorze gazowej, „Ekspres Wieczorny” 1947, nr 217, s. 4.

31 Instytut Śląski w Opolu, Materiaty do biografii...

32 H. Biegańska, Działaczka ślaska..., s. 183.

33 Wywiad z dr Agnieszką Appelt, maszynopis w zbiorach autorki. 


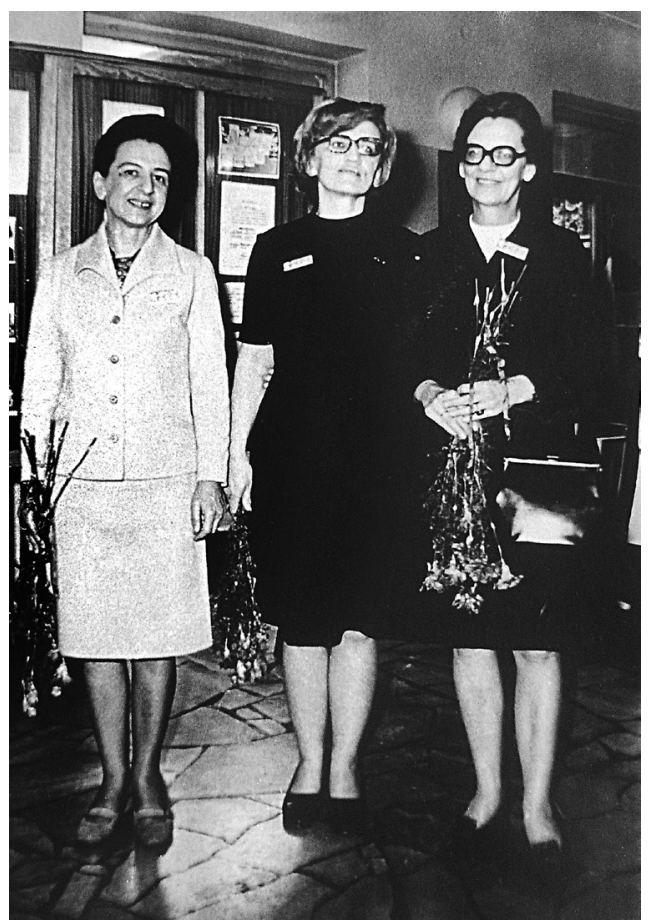

Ryc. 6. Córki dr Marii Kujawskiej

Doktor Maria Kujawska była jednym z tych cichych bohaterów. O takich ludziach zwykło się mówić, że pamięć o nich nie zaginie. Czas zwykle szybko odsuwa w cień ludzi i ich dzieło. W przypadku doktor Marii Kujawskiej tak się jednak nie stało.

W Opolu postanowiono uhonorować osiagnięcia, zauważone przez ówczesne władze miasta, w nazwie Medycznego Studium Zawodowego. W uznaniu tych zasług postanowiono przyznać szkole imię doktor Marii Kujawskiej i ufundować sztandar. Przygotowania do tych ważnych uroczystości rozpoczęły się już we wrześniu 1973 roku, grono pedagogiczne i młodzież spotkała się wtedy z córkami przyszłej patronki szkoły: Aleksandrą Kujawska, Janiną Kujawską i Barbarą Kujawską- Grudzińską. Spotkanie to było okazją do bliższego poznania życia i pracy patronki, córki opowiedziały wiele ciekawych szczegółów z życia swojej matki, które nie znalazły się w oficjalnej biografii. Było to pierwsze, ale nie jedyne spotkanie. Następne miało miejsce $27 \mathrm{kwiet}-$ nia 1974 roku. Był to niezmiernie ważny dzień. Studium miało otrzymać sztandar, ufundowany przez Komitet Rodzicielski jak i również otrzymać przyznane decyzją Wojewody Opolskiego nr 36/74 imię doktor Marii Kujawskiej - ślaskiej lekarki.

Na uroczystość oprócz córek patronki i wielu innych zaproszonych gości przybyły najbliższe współpracownice doktor Kujawskiej, doktor Agnieszka Appelt i Maria Haderowa.

W kolejnych latach młodzież corocznie w kwietniu w dniu patronki szkoły składała przed jej portretem kwiaty. 
Niestety po latach, w 2003 roku w wyniku reorganizacji szkolnictwa medycznego Medyczne Studium Zawodowe w Opolu zostało przekształcone w Państwowa Medyczną Wyższą Szkołę Zawodową w Opolu. Władze uczelni były zainteresowane przejęciem kadry nauczycielskiej i budynków szkoły, ale nie kontynuowaniem tradycji i przyjęciem imienia doktor Marii Kujawskiej. Jej portret przechowywany jest przez wykładowczynie tej uczelni, które były wcześniej nauczycielkami w Medycznym Studium Zawodowym. Może kiedyś ponownie odżyje idea uhonorowania pamięci dr Marii Kujawskiej.

\section{Wykaz źródeł:}

Instytut Ślaski w Opolu, sygn. A 2029, Kujawska Maria, Materiały do bibliografii.

\section{Wykaz literatury:}

1. Bałutis W., Kobiety wczoraj, dziś i jutro, "Głos Polek”, 1939, nr 5-6, s. 11.

2. Biegańska H., Działaczka ślaska Maria Kujawska, „Dzieje Najnowsze”, 1970, nr 1, s. 180.

3. Brożek K., Anioł z Ravensbrück, „Opole”, 1974, nr 4, s. 14.

4. Brożek K., Polska stużba medyczna w powstaniach ślaskich i plebiscycie 1918-1922. Opole 1977.

5. Chrzanowski L., Jak dr Maria Kujawska uratowała swe blokowe towarzyszki od straszliwej śmierci w komorze gazowej, , Ekspres Wieczorny", 1947, nr 217, s. 4.

6. Długajczyk E., Sanacja ślaska 1926-1939. Zarys dziejów politycznych, Katowice 1983.

7. Kędrzyńska W., Sylwetki zasłużonych lekarzy. Dr Maria Kujawska, „Przegląd Lekarski”, 1965, nr 1, s. 166.

8. Orzechowski M., Wojciech Korfanty. Biografia polityczna, Wrocław 1974.

9. Rostek J., Spis lekarzy województwa ślaskiego. Wedtug stanu z dnia 1 lutego 1924 r., „Goniec Śląski Towarzystwo Akcyjne", 1924, s. 4.

10. Stownik medycyny i farmacji Górnego Ślaska, pod red. A. Puzio, t. 1, Katowice 1993.

Relacje:

Wywiad z dr Agnieszką Appelt, maszynopis w zbiorach autorki. 